\title{
Garden, Ars Cooperativa Naturae
}

\author{
Joelmir Marques da Silva* \\ Department of Architecture and Urbanism, Federal University of Pernambuco, Brazil
}

Submission: April 25, 2019; Published: May 09, 2019

*Corresponding author: Joelmir Marques da Silva, Federal University of Pernambuco, Landscape Laboratory, Department of Architecture and Urbanism, Center of Arts and Communication (CAC), Avenida da Arquitetura, s/n, Universidade Federal de Pernambuco, Cidade Universitária, CEP. 50740-550, Recife-PE-Brasil

\section{Abstract}

The garden is an artialization of the natural landscape. In this process of artialization, the elements of nature, especially the vegetation, are applied artistic principles. At this moment, there is an ordering of Nature, but this order is flexible since the vegetation, main element of the garden, have a biological dynamic. Even so, the garden ceases to be a natural nature and becomes a product of the culture of a civilization.

Keywords: Garden; Nature; Landscape; Garden history; Work of art

\section{Mini Review}

Nature is the great metaphor underlying all art. Being the garden one of the most representative themes in the history of figurative art, it existed from the earliest antiquity, being already represented in the low Egyptian reliefs and mentioned in the Norse mythologies in the Utgard duality and Midgard appearing as a place privileged by the tranquility and exuberance of the vegetation. From which one senses that the garden is rather a conscious necessity than simply an accidental creation of superfluous luxury of a civilization [1]. It was in the Renaissance period that man launches himself to the knowledge and management of Nature and turns it into an artifice, and art becomes understood as a mixture of the natural and the artificial where reason excels the genius. Thus, art "modifies" Nature. The fusion of art and nature, carried out by man, results in what is called Terza natura, which benefits from what neither Nature nor art alone can do, reflecting a human way of seeing things, according to which the garden is seen as a cosmological improvement of Nature on the path leading from the wild forest [Prima natura] to art, through agriculture [Seconda natura]. It is at this moment that the garden is "in effect, the Nature modeled by the man to express in it his feeling" [2] in this way, the garden is the bearer of a fundamental message that proclaims the subordination of Nature to art.

Whether the garden is intentionally created with an architectural and plant vision is now considered a work of art. But this is a very special art, the only one that is composed of a living material. So, it is changing, it is a way of life. The garden assuming the condition of a work of art, it must "obey a classical idea, with logical perspectives and subordinated to a certain formula of set" [3]. In this way, the art of the garden is probably the most ambiguous, the most difficult and at the same time the least apprehensible of all the arts. This ambiguity, difficult and less apprehensible art, is because the garden is an art that is different from the others, because in it beauty is not only contemplated but also lived. In the garden, one really lives the art, where the act of contemplating and the act of living form one thing [4]. In the art of gardens, as in the other arts, certain compositional or ordering principles are repeated, which have a close analogy because they have their origin and foundation in the laws of the universe, which reveal themselves in the harmony of forms, spaces and colors. In this sense, the philosopher Arthur Schopenhauer in in your book 'The world as will and representation' [5], presents a chapter devoted to art and its role in which it recognizes that garden art has full autonomy and places it at the forefront of architecture in a system of hierarchical arts. To the author, a garden, as an art, tries to show to the human intuition, the idea that constitutes and the state of the vegetal elements.

Therefore, garden art is inseparable from the idea of representation. On a subjective plane it is fairly easy to see that a garden can never be presented in one look, as in a painting. Thus, the garden art finds us in a situation, "sometimes near and far [...] momentary contemplation of nature never realizes twice the same landscape. Each step creates another reality. To put it another way, every garden is an infinite world that demands an unlimited series of representation" [6]. Thus, "gardens are works of art and the principles of construction of gardens and other works of art are the same: in order to accentuate the principal, 
parallels are established; to emphasize a color, oppose others, create contrasts, harmonies " [7]. After all, a garden is mainly made with Nature itself and, in addition, the vegetation - the main element of the garden - lives in resonance with the environment and there is a correspondence between the conditions of the niche that it occupies and its requirements to be born, grow and reproduce. Vegetation life is a cyclical activity whose interruptions are marked by death and germination" [...] [8]. However, by respecting the requirements of ecological and aesthetic compatibility, artificial associations are created that are very expressive. Thus, the garden is in the expression of St. Thomas an 'ars cooperativa naturae', that is, an art that cooperates with Nature and not only imposes its form [9].

Being the garden "organized nature, subordinated to architectural laws" [10] the organization is partial because in the garden what is imposed is "Nature with its imminent order. The gardens are not renewed in exact situations because they depend on the cycles of Nature. Its characteristic feature is the delicacy of the material itself, which naturally occurs [...]. Therefore, we designated this property as fragile". According to landscaper Carmen Añón Feliú "the artist created the garden at a certain time, which was then changed and transformed. An action that converts time into a creative element" [11]. The idea that a work of art must possess a maximum degree of durability and stability has long been rooted. From the historical point of view, the garden presents itself in relation to the other arts with a totally particular physiognomy. It is questioned, if this art form can be conceived historically, since the gardens are subject to continuous modifications and that all their vitality makes it difficult to formulate a definite critical valuation. Such questioning is not something recent. Garden theorist Christian Cajus Lorenz Hirschfeld (1781) in 'Théorie de l'art des jardins' already stated that "What in one century I call the garden is not the same in the next century" [12] explaining that "the same garden can assume such a connotation, to the point of ceasing to exist even to a distant resemblance to the initial picture." This statement, which brings to the extreme limit the possibility of survival of such a fragile work of art, leads us to reflect on the degree of incidence of time in the perception of the garden idea. However, for Giusti [13], the garden, making an analogy with music and cinema, gets its expressiveness in time.

\section{References}

1. Silva JMS (2017) Integridade visual nos monumentos vivos: os jardins históricos de Roberto Burle Marx. Doctoral Thesis - Post-Graduation in Urban Development, Department of Architecture and Urbanism, Federal University of Pernambuco, Recife, pp. 224.

2. Assunto R (1991) Ontología y teleología del jardín. Tecnos, Madrid, Spain, p. 31.

3. Diario Da Manhã. (1935) 0 Jardim da Casa Forte, p. 1-12.

4. Añón-Feliú C (1995) Del jardín histórico y su rehabilitación. Nueva Revista 40: 116-124.

5. Schopenhauer A (2014) O Mundo como vontade e representação. Abril Cultural, São Paulo (Coleção: Os Pensadores).

6. Jacob M El jardín y la representación: Pintura, cine y fotografía. Siruela (Eds.), Madrid, Spain, p. 12-15.

7. Jornal DO (1979) Brasil. Burle Marx, 70 anos: meu melhor presente seria fazer um jardim na Zona Norte. p. 1.

8. Marx RB (1987) Arte e Paisagem. Nobel, São Paulo. p. 40.

9. Cabral FC (2003) Fundamentos da arquitetura paisagista. Instituto da Conservação da Natureza, Lisboa.

10. Diario Da Manhã (1935) 0 Jardim da Casa Forte. p. 1-12.

11. Añón-Feliú C (1995) Authenticité: Jardin et paysage. UNESCO; ICCRON; ICOMOS, Japan, pp. 221.

12. Hirschfeld CCL (1781) Théorie de l'art des jardines. Weidmann, Leipzig. p. 27-28.

13. Giusti MA (2004) Restauro dei Giardini: teorie e storia. Alinea Editrice, Firenze.

\section{Your next submission with Juniper Publishers will reach you the below assets}

- Quality Editorial service

- Swift Peer Review

- Reprints availability

- E-prints Service

- Manuscript Podcast for convenient understanding

- Global attainment for your research

- Manuscript accessibility in different formats

( Pdf, E-pub, Full Text, Audio)

- Unceasing customer service

Track the below URL for one-step submission https://juniperpublishers.com/online-submission.php 